of metal in the world's affairs is creating further demands on a mining engineer's accomplishments in an ever-widening field of activity and with largerscale operations than ever before. A study of history, ancient and modern, in terms of minerals is fascinating because the growth of nations and the cause of many wars cannot be dissociated from the possession or a determination to secure control of high-grade deposits of essential minerals. The question has been asked, "Who owns the earth ?", and the answer given is "The nation which controls the greatest mineral resources."

\section{Roman Wroxeter}

RECENT excavations on the site of the Roman city of Uriconium, which lies beneath the modern Wroxeter, five miles from Shrewsbury, were described by Miss Kathleen Kenyon, the field director of the excavation, at a meeting of the Society of Antiquaries of London on May 12. Some years ago excavations were carried out with the object of determining the position and character of the defences of the legionaries' camp, but without success, nor has investigation been more successful on the present occasion. Much information, however, has been obtained about the history of the city. It would appear that Uriconium, which was the fourth largest Roman city in Britain, was founded about A.D. 48 as the headquarters of the Fourteenth and Twentieth Legions, of which it was the station while Wales was being subdued. When the legions were moved to Chester, Uriconium became the tribal capital of the Cornovii. Two successive defensive systems of the city have been found, of which the earlier, dating from about the end of the first century of our era, enclosed a much smaller area than the later. This latter dates from the middle of the second century, and encloses about 170 acres. It marks the largest expansion of the town. The structure known as the Baths Building, which was excavated in 1859 , was re-examined. It was found that originally it had not been intended for use as baths, but had consisted of two ranges of large rooms on either side of an enclosed courtyard, with a long two-sided hall beside it. This was built about A.D. 140 and must have formed part of the public buildings, possibly the law courts, of the town. The Forum opposite was nearly contemporary. Not very much later the whole was transformed into an elaborate and complicated bath of the usual Roman type. An interesting discovery was the body of an infant which had been placed below the floor at the time of the alteration, possibly as a foundation burial. At the end of the third century the building was des. troyed by fire, but was restored in a partial and slipshod manner. It remained in use for a further hundred years.

\section{Archzological Exploration in the Panjab}

Although a considerable period of time has elapsed since the Government of India, soon after the discovery of Mohenjodaro and Harappa, decided to allow duly accredited archæological expeditions from outside India to explore Indian archæological sites, little advantage, unfortunately, has been taken of the opportunity. Two American expeditions and one Belgian have visited India, of which the American expedition to the Salt Hills under Dr. H. de Terra, in a series of investigations extending over several years, has produced much valuable palæontological and archæological material. The excavations at Mohenjodaro for the Archæological Survey were conducted by Dr. E. Mackay, who has since been in charge of further investigations in the Indus valley ; but although Dr. Mackay may be regarded as a British excavator, no British expedition has been sent out. This neglect of opportunity is the more to be deplored in view of the evident importance of India for understanding of early cultural development in the Near and Middle East. India itself is now to make an effort to repair this neglect by the inauguration of a "Panjab Exploration Fund", on behalf of which an appeal is issued by Diwan Chaman Lall, president ; Prof. E. Dickinson, acting president ; and Dr. C. L. Fabri, field director. Funds have been collected in India to begin excavation in the coming autumn on the ancient city site of Surkanwali Ali, near Bhera on the Jhelum, where trial excavations have been made recently by the field director of the Fund. These have revealed the existence of at least five superimposed cities, dating from the Moghul period to pre-Buddhist times. The Fund has the support of the principal scholars and notabilities of the Panjab. A considerable sum is required to place the Fund on a permanent basis ; and if a sufficient amount can be raised, it is proposed also to found an ethnographical and archæological museum, for which nucleus collections are already in hand. Contributions should be addressed to the "Panjab Exploration Fund", Imperial Bank, Lahore, or to the London Branch of the Bank, 25 Old Broad Street, London, E.C.2.

\section{Prehistoric Mines in East Africa}

Exploration of a cave in the Njoro Forest Reserve of Kenya by Dr. L. S. B. and Mrs. Leakey has brought to light cultural evidence, which they believe, it is stated by the Nairobi correspondent of The Times (May 23), points to a connexion with prehistoric opal mining on an extensive scale. The excavations have shown that this cave was used as a place for the disposal of the dead of stone age man. The bodies were brought to the cave, placed in a shallow excavation, and burnt to ashes by a fire lit over them. As time went on, the earlier ashes were disturbed by later incinerations, and the remains of at least sixty bodies have been discovered. The large number of cultural objects found include five hundred stone and one thousand bone beads. The stone beads are especially interesting, as among them are specimens of what appear to be jade and opal, as well as rock crystal and green quartz. Attractive jade pendants were also found. Many of the beads are said to show skilful workmanship, and it is therefore suggested that they may have been brought to East Africa by traders from Egypt and Mesopo. tamia. The beads are being submitted to experts in England for examination and report. It has been possible to reconstruct from charred fragments both basket work and rope work, and an exquisitely carved wooden vessel. Dr. Leakey, it is stated, 
attributes the large number of beads found here to trading activities attracted by the opal mines, and, tentatively, suggests 4000 B.c. as a possible date.

\section{Plastics and the Glass Industry}

IN his address to the Fifth Glass Convention held last week at Droitwich under the presidency of Mr. H. S. Williams-Thomas, Dr. V. E. Yarsley stressed the view that plastics are not to be regarded as substitutes for the older materials, glass, wood and metals. Much of the work done on the new transparent plastic materials such as the methacrylate and polystyrol products has been inspired by glass. In aircraft construction, where low weight must combine with security and good optical properties over a wide range of temperature conditions, 'organic glass' has no rival. The technique of the manipulation of these materials has progressed very considerably, but, as was brought out in discussion afterwards, not sufficiently to enable a bottle, for example, to be blown from a plastic mass in the manner in which molten glass is manipulated by fully automatic machinery. Much interest was aroused by the reference by Dr. A. Caress to the optical and other properties of materials of the 'Perspex' type, and Drs. W. M. Hampton and J. C. Peddle pointed out the tremendous range of optical properties furnished by the optical glass manufacturers to comply with the requirements of the instrument makers, and the need for both homogeneity and very precise annealing. It appears that as yet the only serious competition that might be feared in this field is in the manufacture of ophthalmic lenses, and mass-produced lenses of the type used in very cheap cameras.

\section{"Frustration of Science" Exhibition}

THE Scientists' Section of the Left Book Club held an exhibition on May 17-22 at the Unity Theatre, Goldington Street, N.W.1, illustrating "The Frustration of Science". Charts, pictures and select quotations illustrated the contrast between science as a constructive force in society and science as a weapon of destruction, science as a means towards arousing and satisfying communal needs and science merely as an instrument for profit. Side by side with evidence of the increasing concentration on productivity from the soil was shown the destruction of commodities and foodstuffs. Alongside the figures showing the multiplication of productivity was widespread evidence of malnutrition and scarcity. The meagre sum spent on health research was contrasted with that devoted to investigations in chemical warfare; and the repression of scientific work and the destruction of scientific opportunity in Fascist countries were pointedly illustrated. Comparative graphs showed the speed-up in production that follows from rationalization, and the lag that exists between this and the index of wage rates. In the advertising of fictitious remedies for all kinds of diseases, approximately $£ 3,000,000$ per annum is spent, as compared with $£ 139,000$ per annum expended from Government sources on medical research in Great Britain. A total retail turn-over of these remedies amounts to $£ 20,000,000$ per annum.
The exhibition was opened by Prof. P. M. S. Blackett, who dealt with the historical factors that called science into being, and underlined how these same forces were now frustrating it. In discussing the treatment of scientific men in Fascist countries, he stressed its blindly reactionary character, its penalization of scientific workers in the first instance and, in the drive towards war, how later it had become essential to reverse that policy, in order to regain military and aerial efficiency. It was not, he considered, the task of men of science to solve these problems by their action alone, any more than they had alone called this situation into being; but it was their duty to discard their scientific aloofness and to bring their special knowledge and understanding to bear on these social issues in order to show, in terms of social forces, how the present situation had arisen, and so to discover a way out.

\section{Trans-Atlantic Steam Navigation}

IN connexion with the recent commemoration of the centenary of the inauguration in 1838 of transAtlantic steam navigation, an article on which appeared in our issue of March 26, p. 540, Mr. J. W. Morgan, of Springfield, Ohio, has directed our atten. tion to the voyage from Nova Scotia to England in 1833 by the Canadian-built steam vessel Royal William. The performance of this vessel led the Canadian Government in 1895 to place a commemorative tablet on the walls of the Parliament Buildings in Ottawa, on which she is referred to as "The First Vessel to Cross the Atlantic by Steam Power . . . The Pioneer of Those Mighty Fleets of Ocean Steamers by which Passengers and Merchandise of all Nations are now Conveyed on Every Sea through. out the World". The Royal William, of about 800 tons and 200 horse-power, left Pictou on August 17, 1833, and arrived off Cowes, Isle of Wight, nineteen days later. It has sometimes been stated that she crossed under steam power alone, but that statement cannot be substantiated. As Engr.-Capt. Smith was careful to point out in his lecture at the Science Museum on March 16, every steamship both before, and long after 1838, was fitted with sails and made the fullest possible use of the wind. Indeed it is quite impossible to say with certainty what vessel first crossed the Atlantic by steam power alone. The Atlantic had been crossed by the steamers Rising Star, Curacao and Savannah before the Royal William made the passage, but their voyages, like hers, had nothing to do with a considered scheme for a regular service. The true significance of the events of 1838, the year which saw the Atlantic crossed and recrossed by the Sirius, Great Western, Royal William $I I$ and Liverpool, lies in the fact that they were the first vessels placed on the run with the idea of maintaining regular communication between Great Britain and the United States by steam in all weathers and at all times of the year. Of the four ships, it was the Great Western which unmistakably demonstrated the feasibility of the project. She was the true forerunner of our modern Atlantic liners. 